\title{
Palaeomagnetism and rock magnetism of the Tortonian-Messinian boundary stratotype at Falconara, Sicily
}

\author{
C.G. Langereis and M.J. Dekkers \\ Palaeomagnetic Laboratory, Fort Hoofddijk, Budapestlaan 17, 3584 CD Utrecht, Netherlands
}

(Received 19 July 1991; revision accepted 11 September 1991)

\begin{abstract}
Langereis, C.G. and Dekkers, M.J., 1992. Palaeomagnetism and rock magnetism of the Tortonian-Messinian boundary stratotype at Falconara, Sicily. Phys. Earth Planet. Inter., 71: 100-111.

The Tortonian-Messinian boundary stratotype at Stazione Falconara (Sicily) yields normal polarity remanent magnetizations of post-tilting age, implying that the entire section is (sub)recently remagnetized. The absence of direct time control on the biostratigraphic datum levels in the section makes it therefore less suited as a boundary stratotype section. Existing age estimates for the Tortonian-Messinian boundary are discussed; it is concluded that an age of $5.6 \mathrm{Ma}$ is at present the best estimate. Assessment of the magnetic mineralogy in the Falconara section shows that rock magnetic parameters are for a large part lithologically controlled. A second important controlling factor is the numerous joints, which could have acted as channels for circulating groundwater and from which predominantly (sub)recent finely crystalline haematite was precipitated, possibly mediated by weathering processes. This haematite has completely replaced an earlier and presumably magnetite-dominated magnetic mineralogy.
\end{abstract}

\section{Introduction}

The Tortonian-Messinian boundary is marked by the first occurrence (FO) datum of the Globorotalia conomiozea group (d'Onofrio et al., 1975; Colalongo et al., 1979a). It constitutes an important datum level in the Mediterranean Neogene, not least because it preludes the Messinian 'salinity crisis': the desiccation of the Mediterranean which in turn is followed by the Pliocene flooding event. For a detailed magnetostratigraphic study of the Mediterranean upper Miocene, a number of marine clay sections were sampled on Crete and on Sicily. The sections from Crete gave excellent results and showed that the FO of the $G$. conomiozea group occurs in a reversed polarity zone-interpreted to represent the reversed subchron of Chron 5-and conse- quently has an age of 5.6 Ma (Langereis, 1984; Langereis et al., 1984).

The Tortonian-Messinian boundary stratotype itself has been defined in the Falconara section near Stazione Falconara in southern Sicily (Colalongo et al., 1975b); the FO of the G. conomiozea group (Zachariasse and Spaak, 1983) coincides with the level taken as the physical reference point for the Tortonian-Messinian boundary. Evidence for the time equivalence of the FO of the G. conomiozea group in the Mediterranean was strongly suggested by calcareous nannoplankton stratigraphy (Theodorides, 1984). On the basis of this time equivalence, Langereis et al. (1984) concluded that the boundary has an age of $5.6 \mathrm{Ma}$, a conclusion which has led to some controversy (Berggren et al., 1985). Direct magnetostratigraphic control of the boundary stratotype itself 
has been lacking. This study presents the palaeomagnetic and rock magnetic results of the Falconara section. In addition, current data on the age of the Tortonian-Messinian boundary are discussed.

\section{The Falconara section}

The Falconara section is located close to the eastern border of the Caltanisetta basin in central-southern Sicily (Fig. 1). The section consists of Tortonian pelagic marls overlain by an early Messinian diatomite series known as 'Tripoli' (Colalongo et al., 1979; Van der Zwaan, 1979, 1982; Azzarro et al., 1988). The Tortonian marls reflect open marine conditions, whereas the Tripoli sedimentation occurred in small evaporative basins periodically cut off from the open sea (Colalongo et al., 1979a; Bellanca et al., 1986). The blue-grey Tortonian marls are interbedded with brown, occasionally laminated clays. The Tripoli diatomites are typically white and finely laminated; they alternate regularly with light brown marls. This cyclic bedding is probably related to the precessional cycle of the Earth's rotation axis. Four main lithological units can be discerned in the Falconara section (see Fig. 2). The Tortonian marls can be divided into three groups: in the lowest group (I in Fig. 2) brown intercalated laminated beds occur; in the middle group (II) these are absent; and in the upper group (III) they occur most abundantly. Fracturing is most pronounced in the Tortonian marls and is evident from gypsum needles along numerous joints. The Messinian Tripoli forms the up-

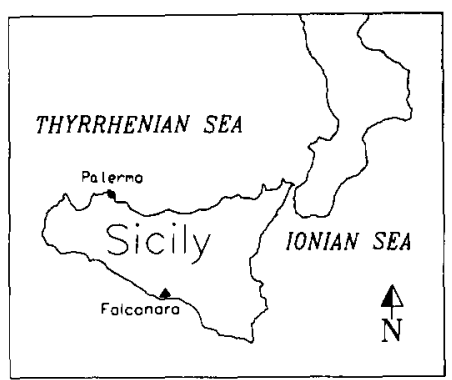

Fig. 1. Location of the Falconara section.

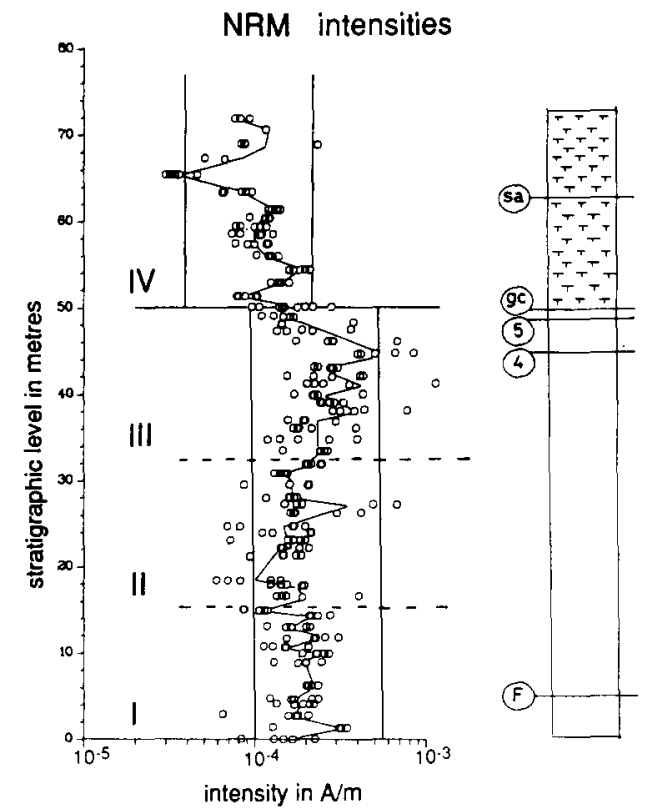

Fig. 2. Lithology, biostratigraphy and initial NRM intensities of the Falconara section. The lower part consists of Tortonian marls, the topmost part consists of an alternation of light brown marls and diatomites ('Tripoli'). sa, Shift in coiling of $N$. acostaensis; gc, FO of $G$. conomiozea; 5 , FO of $G$. menardii form $5 ; 4$, LO of $G$. menardii form 4; F, LO of $G$. falconarae. I-IV denote intervals with different rock magnetic properties (see text).

permost group (IV); this group show no visible jointing.

Biostratigraphically, the Falconara section here considered ranges from the last occurrence (LO) of Globorotalia falconarae to the coiling shift in Neogloboquadrina acostaensis (Fig. 2). Details on the biostratigraphy of the section have been discussed earlier (Colalongo et al., 1979a,b; Van der Zwaan, 1979, 1982; Zachariasse, 1979b; Zachariasse and Spaak, 1983; Theodorides, 1984) and will not be reiterated here. It should be noted, however, that there is a considerable discrepancy in the relative distances between the LO of Globorotalia menardii 4, the FO of Globorotalia menardii 5 and the FO of $G$. conomiozea, if one compares the datum levels from Crete (Zachariasse, 1979a; Langereis et al., 1984), the Tyrrhenian Sea (Glaçon et al., 1990) and Falconara: in the Falconara section the FO of $G$. conomiozea follows the $\mathrm{FO}$ of $G$. menardii 5 
immediately almost, indicating an abrupt decrease in sedimentation rate or the presence of a fault. Indeed, F.J. Hilgen (personal communication, 1990) pointed to the extreme variability of biostratigraphic results, even between adjacent sampling tracks, which probably indicates ubiquitous (small-scale) faulting.

Samples were obtained by drilling cores in the field, using a water-cooled electric drill and a portable generator. Much effort was made to remove the weathered surface and to drill in fresh sediment. Because of the fracturing and the numerous joints, this often proved difficult, and cores could be drilled only in the centre of usu- ally small blocks. The bedding plane has a strike of $229^{\circ}$ and a dip of $24^{\circ} \mathrm{W}$.

\section{Palaeomagnetic and rock magnetic results}

\subsection{Demagnetization}

The natural remanent magnetization (NRM) was measured using an ScT cryogenic magnetometer. The initial NRM directions scatter around the present geomagnetic field direction. Intensities for the blue-grey marls are low $(0.10$

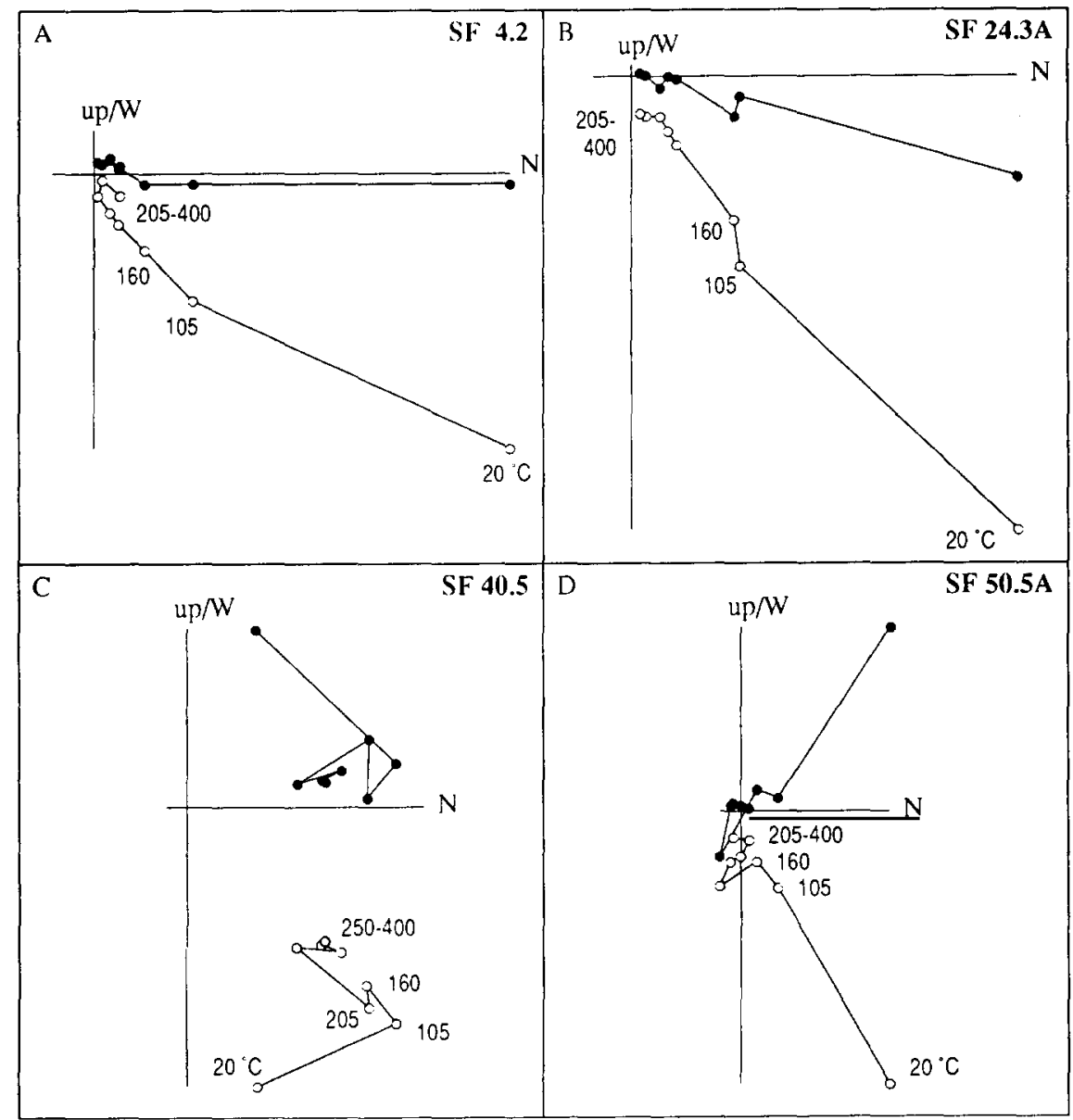

Fig. 3. Representative thermal (A-D) and a.f. (E-H) demagnetization vector diagrams of some selected Falconara section samples before tilt correction. Solid (open) circles denote projection on the horizontal (vertical) plane; numbers indicate temperatures $\left({ }^{\circ} \mathrm{C}\right.$ ) or alternating fields $(\mathrm{mT})$. 


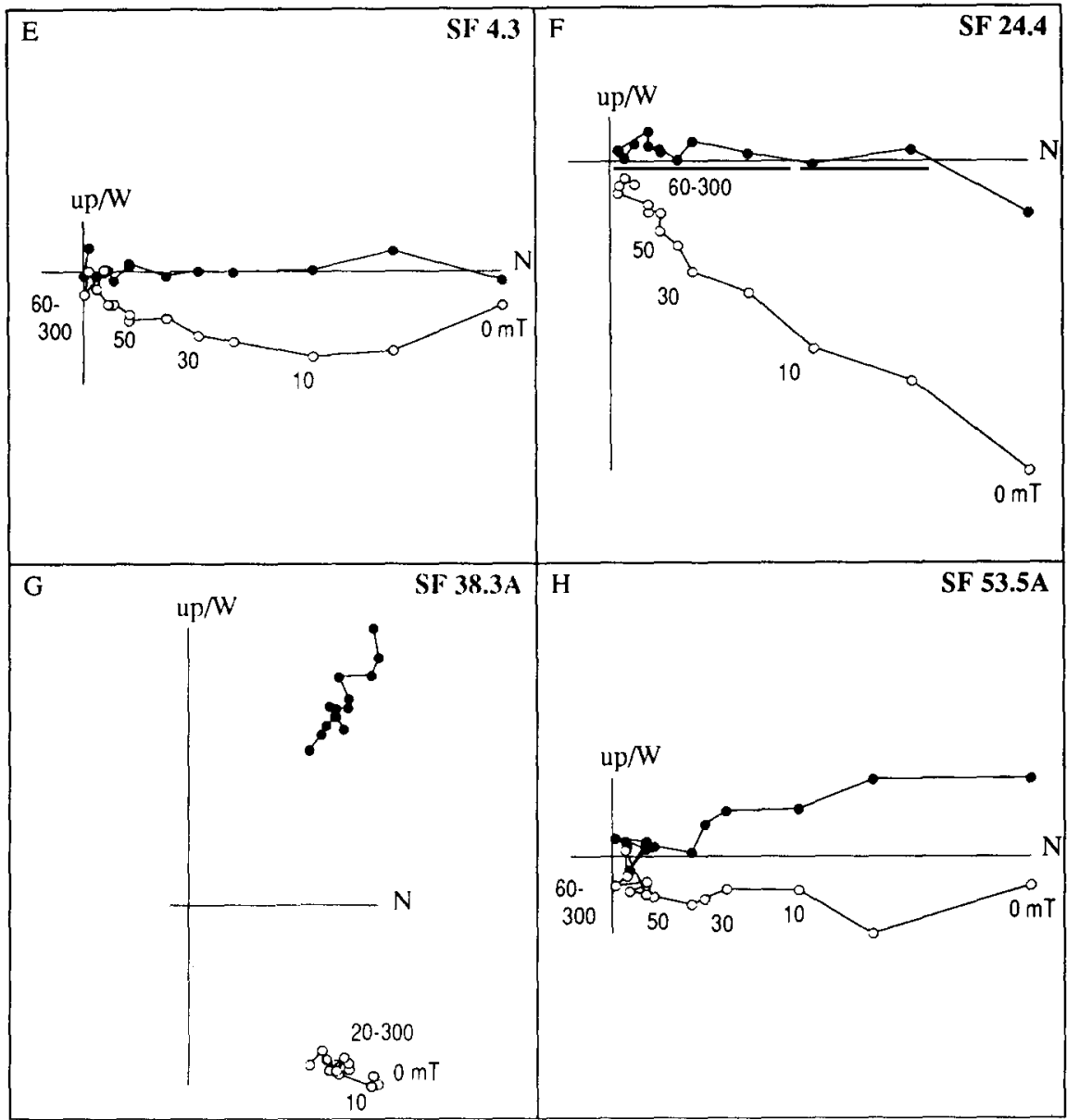

Fig. 3 (continued).

$0.50 \mathrm{~mA} \mathrm{~m}^{-1}$ ) and those for the marls from the overlying diatomite-marl sequence are even lower $\left(0.04-0.20 \mathrm{~mA} \mathrm{~m}^{-1}\right)$. These lower intensities seem to be inherent to differing lithologies with presumably varying magnetic mineral contents. At least one specimen per sampling level was stepwise thermally demagnetized, and one more was demagnetized by means of alternating fields (a.f.).

Stepwise thermal demagnetization shows that very often a large component is removed at low heating temperatures of $100^{\circ} \mathrm{C}$ (Figs. 3A-D), indicating either a large viscous remanent magnetization (VRM) which is laboratory induced, or a secondary chemical remanent magnetization (CRM) which is of (sub)recent origin. The rather random character of the directions of this compo- nent is in favour of a laboratory-induced remanence.

From the lower part of the section (groups I and II), general $20-40 \%$ of the initial NRM survives heating to $100^{\circ} \mathrm{C}$ (Figs. $3 \mathrm{~A}$ and $\mathrm{B}$ ). In the middle part (group III), $50-70 \%$ of the NRM survives heating to this temperature (Fig. 3c). The Tripoli marls in the top of the section (group IV) show NRM intensities after heating to $100^{\circ} \mathrm{C}$ that are one order of magnitude lower than those in the Tortonian clays and marls; only $20 \%$ of the initial NRM remains after heating to $100^{\circ} \mathrm{C}$ (Fig. 3D). After removal of this $100^{\circ} \mathrm{C}$ component, the intensities decrease quickly to $0.020 \mathrm{~mA} \mathrm{~m} \mathrm{~m}^{-1}$ or lower at some $250-300^{\circ} \mathrm{C}$, which is close to the accuracy level of the magnetometer. Demagneti- 

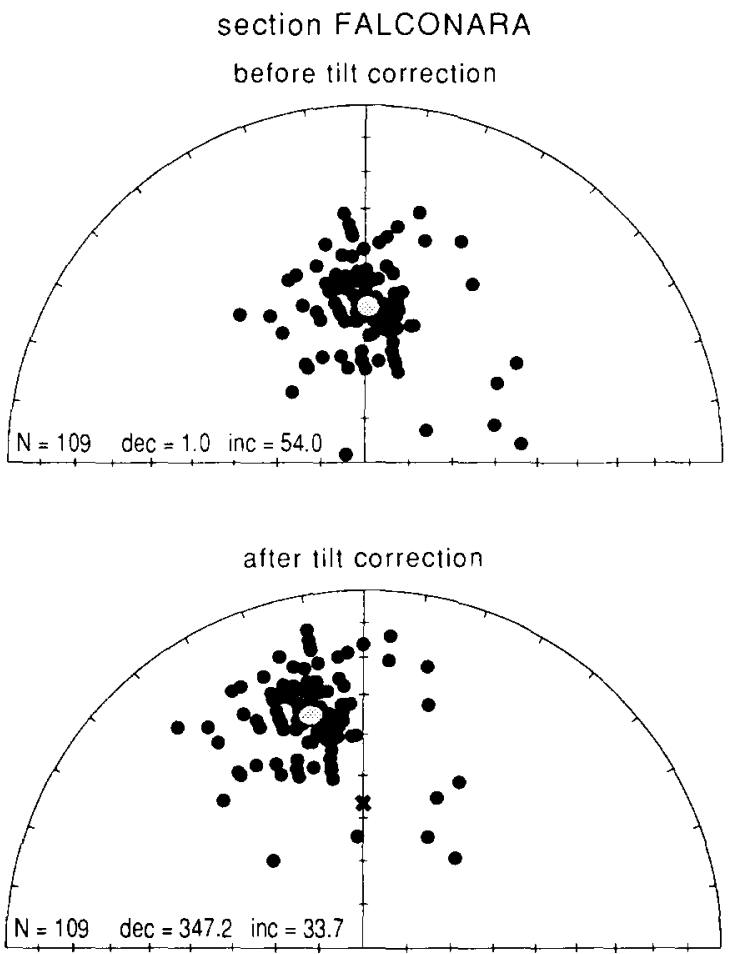

Fig. 4. Characteristic remanent magnetization directions before and after bedding tilt correction. The mean direction (shaded area includes the $95 \%$ level cone of confidence of $2.5^{\circ}$ ) is not distinguishable from the geocentric axial dipole field direction (inclination 56.4 $4^{\circ}$ ) for the present latitude (cross in lower figure). The sum of unit vectors $R$ is 105.52 , and the precision parameter $k$ is 31.0 (Fisher, 1953).

zation at higher temperatures yields inconsistent results: normal polarity or directional scatter is obtained. Directions have been obtained by least-squares fitting (Kirschvink, 1980), from steps at temperatures higher than $160^{\circ} \mathrm{C}$ and always including the origin (Fig. 4).

Alternating field demagnetization (Figs. 3E-H) reveals a soft NRM behaviour: a relatively large and approximately northerly directed component with a low inclination is removed at $20-30 \mathrm{mT}$. At higher alternating fields $(50-100 \mathrm{mT}$, occasionally up to $300 \mathrm{mT}$ : Fig. $3 \mathrm{G}$ ) the demagnetization results show a cluster with directions of normal polarity (Figs. $3 \mathrm{E}, \mathrm{F}$ and $\mathrm{H}$ ). In groups I and II the NRM can be considered as removed at 100-200 mT (Figs. 3E and F), whereas in group IV it is already removed at some $50-100 \mathrm{mT}$ (Fig.
$3 \mathrm{H}$ ). However, in group III a large part of the NRM persists after the maximum peak a.f. demagnetization step of $300 \mathrm{mT}$ (Fig. 3G), pointing to stable goethite or haematite as remanence carrier. Directions have usually been obtained from steps at fields higher than $50 \mathrm{mT}$, or occasionally higher than $30 \mathrm{mT}$, and always including the origin (Fig. 4).

The removal of the soft NRM component points to a laboratory-induced VRM. Such a viscous magnetization is also not stable to thermal demagnetization (e.g. Pullaiah et al., 1975). The observed large remanence decay after the $100^{\circ} \mathrm{C}$ step during stepwise thermal demagnetization concurs with that inferred from theory. The possibility that the remanence component represents a stable CRM residing in goethite is less likely, given the low a.f. stability of the component. There are, however, goethite remanences carried by extremely finely crystalline goethite, which show an appreciable decay during a.f. demagnetization (Dekkers, 1989). Such goethite, however, is also prone to the acquisition of unstable viscous remanence, as it shows the largest viscous decay. Therefore, on the basis of NRM behaviour alone, we cannot decide between VRM and CRM. In the case of Falconara, the existence of a meaningful NRM component residing in goethite is unlikely, because, during thermal demagnetization of a $2 \mathrm{~T}$ isothermal remanent magnetization (IRM), a large part of the remanence persists after the $360^{\circ} \mathrm{C}$ step (Fig. 5). A goethite IRM would have been completely removed after heating to approximately $100^{\circ} \mathrm{C}$.

The remanence directions in the Falconara section-after removal of viscous components and without correction for the bedding tilt-scatter around the geocentric axial dipole field direction for the present latitude of the section (Fig. 4). Correction for bedding tilt results in a significant deviation from this field direction; this suggests that the remanence is of secondary nature and that it postdates the tilting of the section (Fig. 4). This secondary nature also follows from a comparison with the combined magnetostratigraphic and biostratigraphic results from Crete: the LO of $G$. menardii 4, the FO of $G$. menardii 5 and the FO of $G$. conomiozea were found in three 

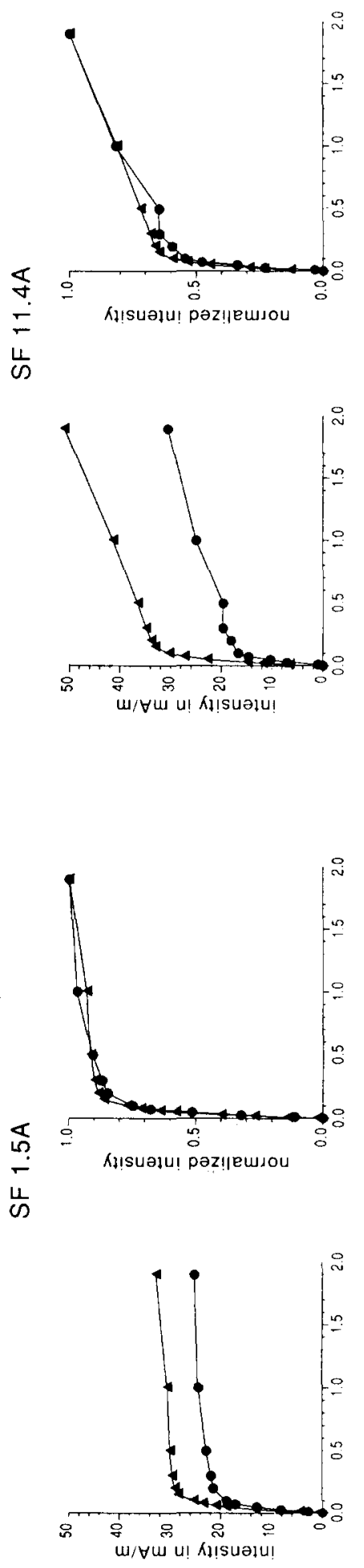
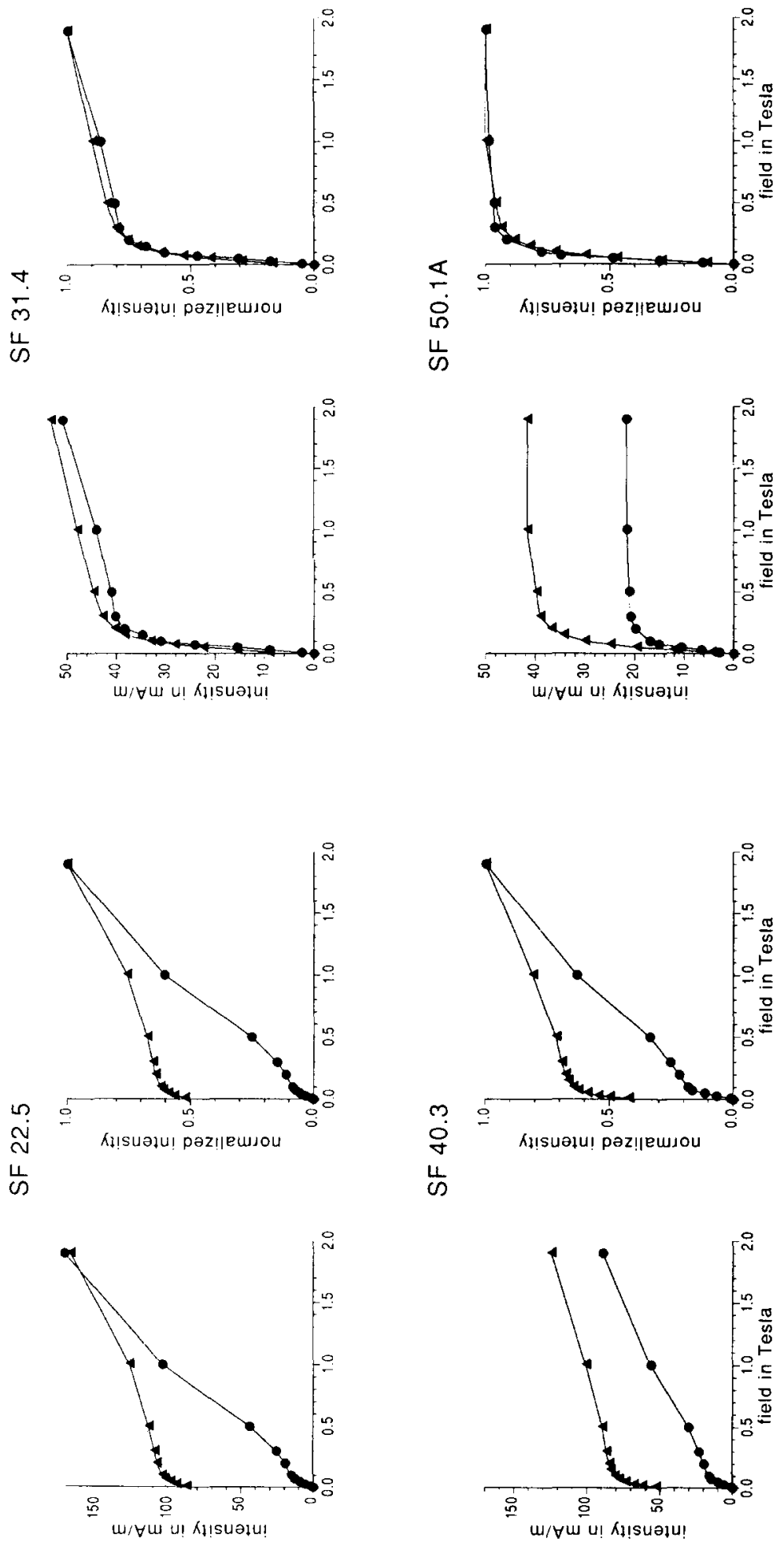
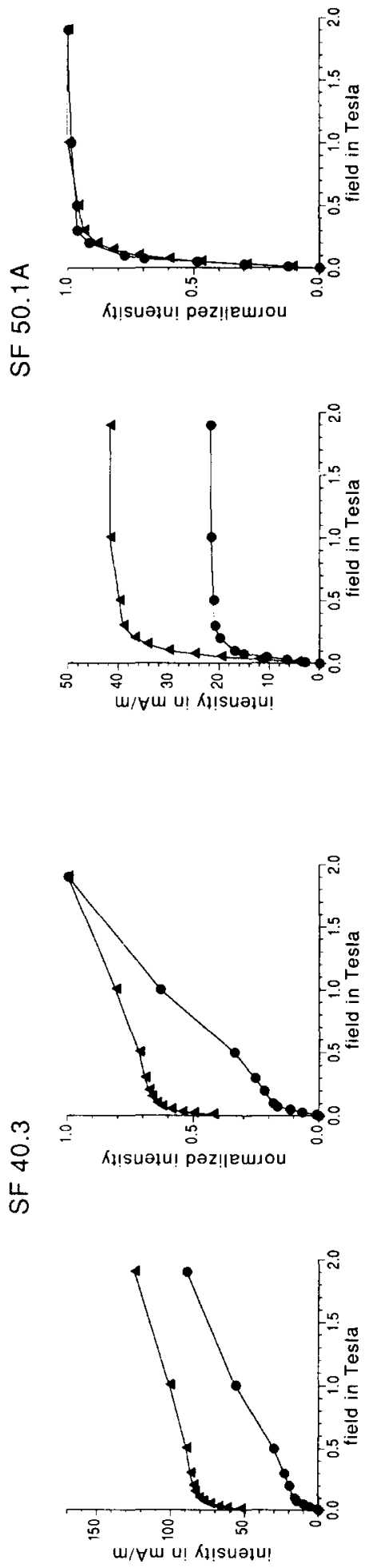

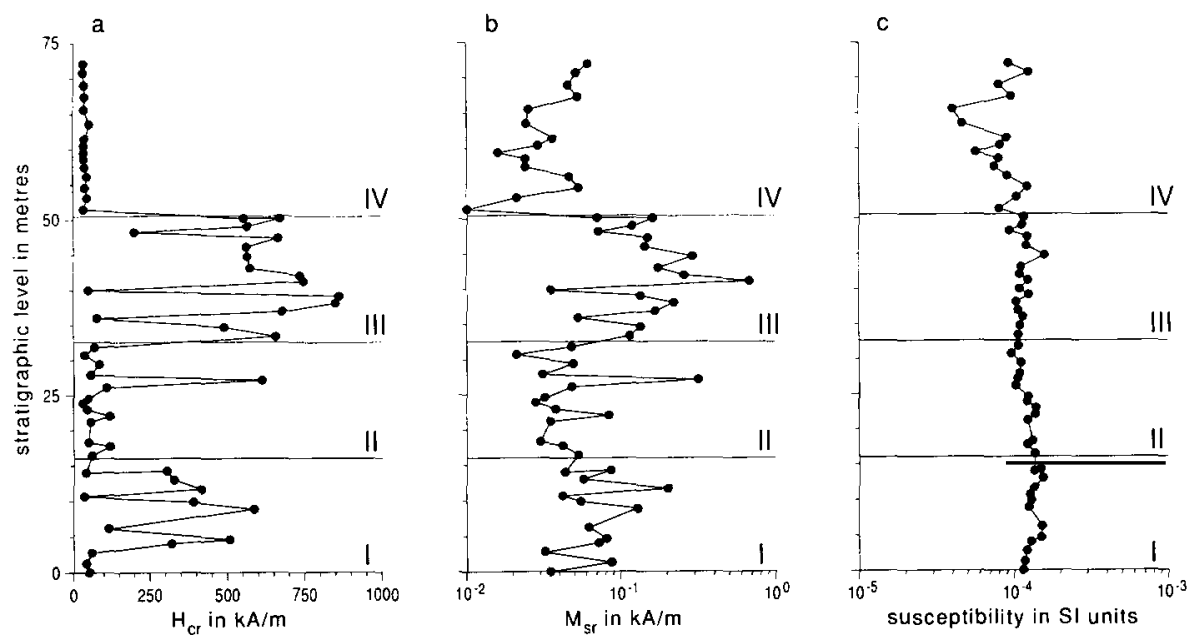

Fig. 6. Lithological variation of some rock magnetic parameters. (a) $H_{c r}$ shows consistently low values in the diatomite-marl sequence (group IV), whereas highest values are found in intervals with regularly interbedded brown laminated marls (groups I and III). (b) $M_{\mathrm{sr}}$ is taken as equivalent to IRM at $2 \mathrm{~T}$ and shows lowest values in group IV and highest values in group III. (c) Initial low field susceptibility $\chi_{\text {in }}$, showing generally low and constant values, presumably indicating an important paramagnetic contribution to $\chi_{\mathrm{in}}$.

successive reversed polarity zones (Langereis, 1984; Langereis et al., 1984), whereas the same datum levels in Falconara occur in only one normal polarity zone.

\subsection{Rock magnetism}

The undoubtedly secondary nature of the NRM in Falconara raises problems concerning in which magnetic minerals the remanence is residing and how it was acquired. To this end, IRM acquisition curves and a set of rock magnetic parameters were determined: the low-field or initial susceptibility $\left(\chi_{\text {in }}\right)$, the saturation remanent magnetization $\left(M_{\mathrm{sr}}\right)$, and the remanent coercive force $\left(H_{\mathrm{cr}}\right)$ (Fig. 6).

IRM acquisition curves of unheated samples (Fig. 5) indicate the presence of a low-coercivity mineral (magnetite/maghemite) which is satu-

Fig. 5. IRM acquisition curves of unheated samples (circles), and renewed IRM acquisition curves after a.f. demagnetization at $300 \mathrm{mT}$ plus thermal demagnetization at $360^{\circ} \mathrm{C}$ (triangles). Both normalized and unnormalized IRM acquisition curves are shown. SF $1.5 \mathrm{~A}$ and $11.4 \mathrm{~A}$ belong to group $\mathrm{I}, \mathrm{SF}$ 22.5 to group II, SF 31.4 and 40.3 to group III, and SF 50.1A to group IV. rated in low d.c. fields $(0.2-0.3 \mathrm{~T})$, and a highcoercivity mineral (haematite or goethite) which is not entirely saturated in the maximum available d.c. field $(2 \mathrm{~T})$. Both goethite and haematite may be inferred from the shape of the curves for the high-coercivity minerals: there is hardly any IRM acquisition in fields up to $0.5 \mathrm{~T}$. IRM acquisition curves start to rise rather steeply at higher field strength values. A typical example is that of sample SF22.5 (Fig. 5). Lowrie and Heller (1982) showed similar curves for goethite, but noted that these curves are often indistinguishable from haematite IRM acquisition curves. To distinguish between goethite and haematite, first the IRM of all samples was a.f. demagnetized at $300 \mathrm{mT}$ to remove any magnetite contribution to the IRM, and then the samples were heated to $360^{\circ} \mathrm{C}$. The IRM acquisition curves were then determined once more in the same samples (Fig. 5) to study possible changes in magnetic mineral content and coercivity behaviour.

After heating to $360^{\circ} \mathrm{C}$, goethite IRM would have been demagnetized and goethite itself-if present-would have been converted to haematite. However, after the $360^{\circ} \mathrm{C}$ demagnetization step a large part of the remanence remained in the Falconara samples, indicating that haematite 
with fairly low unblocking temperatures is the magnetically dominant mineral.

The IRM behaviour of the magnetitedominated sample SF 31.4 (Fig. 5) before and after the heating procedure is very similar, indicating that its magnetic mineralogy has not changed upon heating at $360^{\circ} \mathrm{C}$. However, in other magnetite-dominated samples (SF 1.5A, SF 11.4A and SF 50.1 in Fig. 5), a substantial remanence increase for the low-coercivity component is usually observed during the renewed IRM acquisition. The increased low-coercivity remanence values must be due to the creation of trace amounts of magnetite-like minerals, presumably through reduction of very fine-grained haematite under the influence of decaying organic matter. The normalized IRM acquisition curves before and after demagnetization at $360^{\circ} \mathrm{C}$ (Fig. 5) are very similar for SF 1.5A and SF 50.1 and to a lesser extent also for SF 11.4A, because magnetite IRM can be completely demagnetized with alternating fields of $300 \mathrm{mT}$. If the samples contain an appreciable haematite IRM (samples SF 22.5 and SF 40.3) this is not the case: the remanence remaining after $300 \mathrm{mT}$ a.f. demagnetization and after thermal demagnetization at $360^{\circ} \mathrm{C}$ is considerable, causing the starting point for the renewed IRM acquisition curve to deviate markedly from zero. This hinders an exact comparison of possible changes in coercivity for the high-coercivity component, although for both samples the coercivity seems to be similar before and after thermal treatment, as can be deduced from the nonnormalized IRM acquisition plots. An increase of the magnetite component in samples SF 22.5 and SF 40.3 can be noted: the low-coercivity contribution is slightly enlarged.

The observed IRM behaviour after the $360^{\circ} \mathrm{C}$ step does not support the presence of goethite in the original samples, because haematite derived from goethite is extremely hard and has a very small remanence, smaller than that of the original goethite (Dunlop, 1971; Dekkers, 1990). Neither increasing hardness nor decreasing IRM is observed.

The variation in $\chi_{\mathrm{in}}, M_{\mathrm{sr}}$ and $H_{\mathrm{cr}}$ as a function of stratigraphic level is plotted in Fig. 6. The lithological differences (groups I-IV) are re- flected in most rock magnetic parameters. Pronounced differences are observed for $H_{\text {cr }}$ (Fig. 6a): the diatomite-bearing group IV shows values which are low and very constant (32-45 $\mathrm{kA} \mathrm{m}^{-1}$ ), whereas it ranges from some 40 to $100 \mathrm{kA} \mathrm{m}^{-1}$ in group II, and from some 40 to more than 300 or even $500 \mathrm{kA} \mathrm{m}^{-1}$ in stratigraphic intervals with brown laminated beds (group I and notably group III). $M_{\mathrm{sr}}$ shows a similar variation: a 'base' level of $0.02-0.04 \mathrm{~A} \mathrm{~m}^{-1}$ with increasing values in group I and especially in group III (Fig. 6b). In contrast, $\chi_{\text {in }}$ shows only a marginal variation, with a tendency to decrease slightly in the diatomitebearing group IV of the section (Fig. 6c). This indicates that a considerable fraction of $\chi_{\text {in }}$ is the result of the paramagnetic minerals, implying that interparametric ratios including $\chi_{\text {in }}$ have to be interpreted with care.

An important observation is the following: it is apparent that samples with low $H_{\text {cr }}$ values are also characterized by low $M_{\text {sr }}$ values (Fig. 6). The haematite-rich samples-broadly characterized by high $H_{\text {cr }}$ values-are thus not formed by oxidation of previously existing magnetite, as, in that case, one would expect $M_{\text {sr }}$ to be lowered with increasing $H_{\mathrm{cr}}$. The observation of an equal or increasing $M_{\mathrm{sr}}$ with increasing $H_{\mathrm{cr}}$ must therefore point to the addition of haematite. A conceivable mechanism for this haematite addition is transport of ferrous iron in solution which is precipitating as haematite in oxidizing conditions (for example, created by weathering). During this precipitation process, the existing magnetite may also be oxidized. Precipitation of haematite need not exclude a viscous origin for the NRM, but makes a CRM more likely. High $H_{\mathrm{cr}}$ and $M_{\mathrm{sr}}$ are expressed most prominently in group III, pointing towards weathering. Indeed, in group I and especially in group III, brown laminated beds occur most abundantly. The dominance of high-coercivity minerals is therefore probably governed by the frequency of these brown laminated beds, yielding a variable magnetic mineralogy. This is also inferred from the occasionally large differences between specimens from the same level.

The initial NRM intensity correlates with $\chi_{\text {in }}$ in group IV, whereas no correlation is observed in groups I-III (Fig. 7a). Variations in $\chi_{\text {in }}$, though 

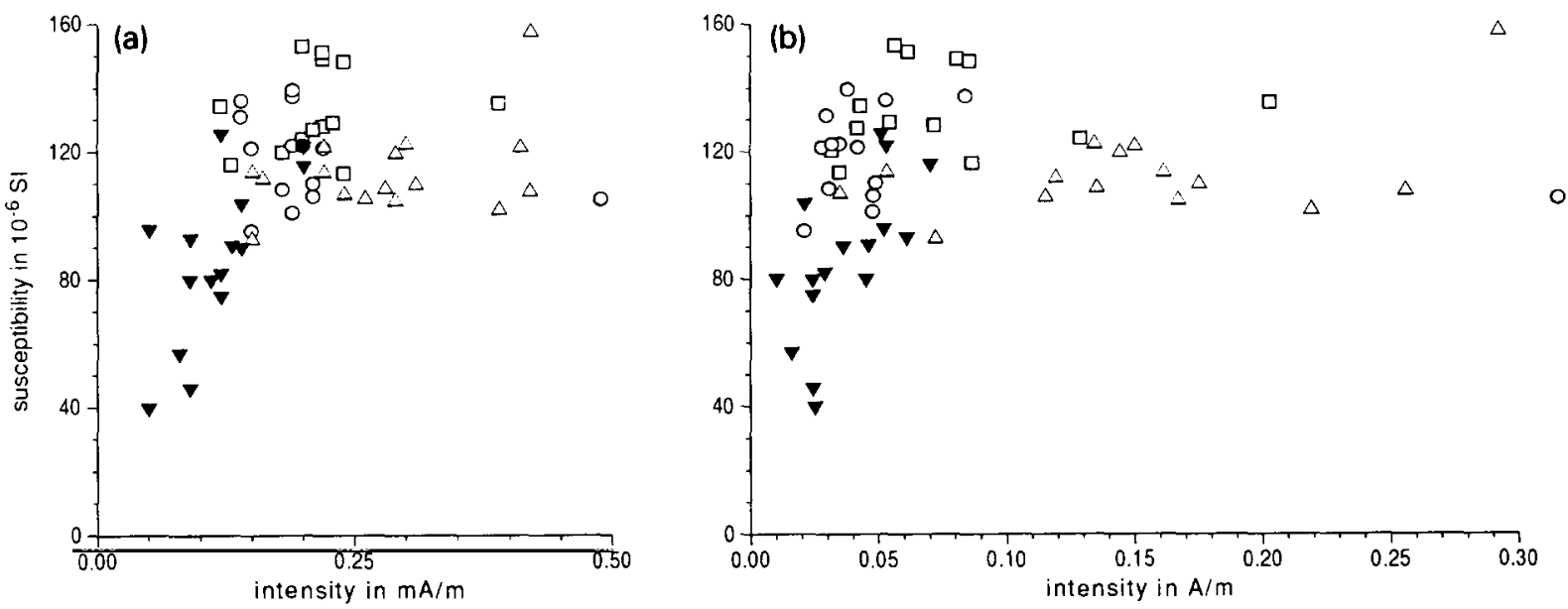

Fig. 7. Initial NRM intensity vs. low field susceptibility $\left(\chi_{\text {in }}\right)$ for the four groups. The initial NRM intensity correlates only with $\chi_{\text {in }}$ in group IV (solid inverted triangles), whereas no correlation is observed in groups I-III (open squares, circles and triangles, respectively). This probably implies that variations in $\chi_{\text {in }}$ in group IV are due to (small) variations in the magnetite content.

they are small as a result of the paramagnetic contribution, are due to (small) variations in the magnetite content $\left(H_{\mathrm{cr}}\right.$ is virtually constant throughout group IV), because unreasonably large variations in paramagnetic mineral content would be required to explain even the observed small $\chi_{\text {in }}$ variations. This is supported by the fact the $\chi_{\text {in }}$ correlates with $M_{\mathrm{sr}}$ in group IV, whereas no evident correlation is observed in groups I-III (Fig. 7b). Hence, the NRM in group IV probably resides in very fine-grained magnetite, and is of viscous origin.

\section{Discussion}

From the palaeomagnetic and rock magnetic results it has become clear that the entire Falconara section shows only recent, normal polarity magnetizations: the remanence directions scatter around the geocentric axial dipole field direction before bedding tilt correction. Furthermore, rock magnetic properties are for a large part lithologically controlled and suggest that haematite, possibly precipitated from circulating groundwater, has replaced an earlier magnetic mineralogy. There- fore, the Tortonian-Messinian boundary cannot be dated, or compared with other sections, by means of magnetostratigraphic control in the boundary stratotype section itself. This implies that dating of the Tortonian-Messinian boundary must rely on the age of this FO of G. conomiozea as determined in other sections within the Mediterranean. However, reported ages have raised a controversy.

An age of 5.6 Ma for the FO of G. conomiozea in the Mediterranean has been established in Crete (Langereis et al., 1984). However, Berggren et al. (1985) rejected this age estimate and suggested that the Cretan results were incorrectly interpreted. Their arguments were essentially based on the age for the Miocene-Pliocene boundary - which recently was shown to be considerably younger (Zijderveld et al., 1986; Channell et al., 1988; Hilgen and Langereis, 1988)and an assumed global synchronism of biostratigraphic datum levels-which is no longer tenable (see, for example, Hodell and Kennett (1986)). In addition, the relation between Pacific and Mediterranean taxa is uncertain (Scott, 1980). The most important argument concerns the presence of the late Miocene carbon isotope shift 
with respect to several biostratigraphic datum levels. However, this shift appears to be a gradual event and is therefore less suited as a reliable time marker. For instance, at ODP Site 588, the shift has been interpreted to begin at $6.9 \mathrm{Ma}$ and reach a minimum near 5.9 Ma (Hodell and Kennett, 1986). In the Mediterranean, stable isotope records for the late Miocene and the Pliocene display a similar gradual carbon shift, reaching a minimum which virtually coincides with the FO of the $G$. conomiozea group (Van der Zwaan and Gudjonsson, 1986).

In the Atlantic margin of western Morocco, the FO of $G$. conomiozea has been found to occur in a normal polarity zone, interpreted as the normal subchron of Chron 6 (Moreau et al., 1985). Although the authors cautioned against circular reasoning, they found it not 'necessary to postulate a noticeable shift' between their FO and the one from Blind River, New Zealand (i.e. 6.1 Ma; Loutit and Kennett, 1979). They thus arrived at an age of $6.44 \mathrm{Ma}$. Correlation of Moreau et al.'s polarity sequence with Chron 5, on the other hand, would result in an age of 5.8 Ma, implying an even less 'noticeable shift' between their FO and the age of 5.6 Ma on Crete.

Also, Channel et al. (1990a) derived an age of $6.44 \mathrm{Ma}$ for the FO of $G$. conomiozea in the Mediterranean, based on the results of ODP Site 654. However, the quality of the magnetostratigraphy is admittedly very poor and several long gaps exist in the record. Two possible interpretations for the age of the Tortonian-Messinian boundary yield an older age of $6.4 \mathrm{Ma}$ and a younger age of $5.4 \mathrm{Ma}$. Consistency of sedimentation rates (Channell et al., 1990b) and nannofossil biostratigraphy (Kastens and Mascle, 1990) have been used to support the older date. In addition, it has been argued that this result is supported by data from the Blind River (Edwards, 1987) which gave an age of $6.44 \mathrm{Ma}$ both for the FO of $G$. conomiozea and the carbon shift. However, the FO nannofossil datum levels are suspect because of possible reworking of the fauna (Kastens and Mascle, 1990). A reinterpretation of the carbon isotope data of Site 654 (Glaçon et al., 1990) by Kastens and Mascle (1989) strongly support the younger age of $5.4 \mathrm{Ma}$ for the $\mathrm{FO}$ of $G$. conomiozea at Site 654. Furthermore, if we assume that the normal polarity interval containing the FO of $G$. conomiozea represents the entire Chron 5, not only would we arrive at an age of 5.6 $\mathrm{Ma}$ for this datum level, but also we would find that the FO of $G$. menardii form 5 (Channell et al., 1990a) would coincide exactly with the FO of this species on Crete (Langereis et al., 1984), just below Chron 5. There would, in this case, remain only a slight discrepancy with respect to the LO of $G$. menardii form 4 .

The results from the Blind River section are not unambiguous. The original data of Kennett and Watkins (1974) were reinterpreted by Loutit and Kennett (1979) to give an age of 6.1 Ma for the FO of $G$. conomiozea. More recently, an age of $6.44 \mathrm{Ma}$ was given to the same datum level in the same section (Edwards, 1987). To establish detailed polarity reversal records in the southern hemisphere (C. Laj, personal communication, 1990), extensive resampling has been carried out in the Blind River section and has led to a revised magnetostratigraphy which now interprets the $\mathrm{FO}$ of $G$. conomiozea to occur at $5.65 \mathrm{Ma}$ (Turner et al., 1989). In addition, Hodell and Kennett (1986) have found an age of 5.61 Ma for this FO at Site 588 , which they used as their reference site for the SW Pacific and for which a magnetostratigraphy has been established (Barton and Bloemendal, 1985). Correlation with other sites in the SW Pacific yields slightly different ages of $5.32 \mathrm{Ma}$ (Site 590) and 5.75 $\mathrm{Ma}$ (Site 284) which are interpreted as a diachrony of the FO $G$. conomiozea in the SW Pacific.

We conclude that the age of $5.6 \mathrm{Ma}$ for the FO of $G$. conomiozea (Langereis, 1984; Langereis et al., 1984) is increasingly supported by recent data. However, we note that the suggested diachronous character of this FO (Hodell and Kennett, 1986) and possible taxonomic problems (Zachariasse, 1979b; Scott, 1980) make it less suited as a marker for a chronological boundary, i.e. the TortonianMessinian boundary. However, even if we accept the FO of $G$. conomiozea to denote the Tortonian-Messinian boundary, the absence of any magnetostratigraphic control in the Falconara section makes this section a most unfortunate boundary stratotype section. 


\section{Acknowledgements}

P.J. Verplak was very helpful both during the collection of samples and the laboratory treatment. J.D.A. Zijderveld and W.J. Zachariasse critically read the manuscript.

\section{References}

Azzarro, E., Bellanca, A. and Neri, R., 1988. Clay mineral studies of the Tripoli Formation (Lower Messinian), Sicily. Clay Miner., 23: 309-321.

Barton, C.E. and Bloemendal, J., 1985. Paleomagnetism of sediments collected during Leg 90, Southwest Pacific. In: J.P. Kennett, C.C. von der Borch et al. Initial Reports of the Deep Sea Drilling Project, 90. US Government Printing Office, Washington, DC, pp. 1273-1316.

Bellanca, A., Calderone, S. and Neri, R., 1986. Isotope geochemistry, petrology and depositional environments of the diatomite-dominated Tripoli Formation (Lower Messinian), Sicily. Sedimentology, 33: 729-743.

Berggren, W.A., Kent, D.V. and van Couvering, J.A., 1985. Neogene chronology and chronostratigraphy. In: N.J. Snelling (Editor), Geochronology and the Geologic Record. Geol. Soc. London Mem., 10: 211-260.

Channell, J.E.T., Rio, D. and Thunell, R.C., 1988. Miocene/ Pliocene boundary magnetostratigraphy at Capo Spartivento, Calabria, Italy. Geology, 16: 1096-1099.

Channell, J.E.T., Rio, D., Sprovieri, R. and Glaçon, G., 1990a. Biomagnetostratigraphic correlations from Leg 107 in the Tyrrhenian Sea. In: K.A. Kastens, J. Mascle et al., Proc. ODP, Sci. Results, 107: 669-682.

Channell, J.E.T., Torii, M. and Hawthorne, T., 1990b. Magnetostratigraphy of sediments recovered at Sites 650, 651, 652, and 654 (Leg 107, Tyrrhenian Sea). In: K.A. Kastens, J. Mascle et al. Proc. ODP, Sci. Results, 107: 335-346.

Colalongo, M.L., di Grande, A., d'Onofrio, S., Gianelli, L., Iaccarino, S., Mazzei, R., Romeo, M. and Salvatorini, G., 1979a. Stratigraphy of Late Miocene Italian sections straddling the Tortonian-Messinian boundary. Boll. Soc. Paleont. Ital., 18: 258-302.

Colalongo, M.L., di Grande, A., d'Onofrio, S., Gianelli, L., Iaccarino, S., Mazzei, R., Poppi Brigatti, M.F., Romeo, M., Rossi, A. and Salvatorini, G., 1979b. A proposal for the Tortonian-Messinian boundary. Ann. Géol. Pays Hell., Tome Hors Série, I: 285-294.

Dekkers, M.J., 1989. Magnetic properties of natural goethite -II. TRM behaviour during thermal and alternating field demagnetization and low-temperature treatment. Geophys. J., 97: 341-355.

Dekkers, M.J., 1990. Magnetic properties of natural goethite -III. Magnetic behaviour and properties of minerals originating from goethite dehydration during thermal demagnetization. Geophys. J. Int., 103: 233-250.
D'Onofrio, S., Gianelli, L., Iaccarino, S., Morlotti, E., Romeo, E., Salvatorini, G., Sampo, M. and Sprovieri, R., 1975. Planktonic foraminifera of the Upper Miocene from some Italian sections and the problem of the lower boundary of the Messinian. Boll. Soc. Paleont. Ital., 14: 177-196.

Dunlop, D.J., 1971. Magnetic properties of fine particle hematite. Ann. Geophys., 27: 269-293.

Edwards, A.R., 1987. Significant climatic vents in the Late Neogene marine strata of New Zealand. In: J.A. Barron and J.R. Blueford (Editors), Fourth International Congress on Pacific Neogene Stratigraphy, 29-31 July 1987, Berkeley, CA. Math/Science Nucleus, Fremont, CA, pp. 26-27.

Fisher, R., 1953. Dispersion on a sphere. Proc. R. Soc., Ser. A, 217: 295-305.

Glaçon, G., Vergnaud Grazzini, C., Iaccarino, S., Rehault, J.-P., Randrianasolo, A., Francisco Sierro, J., Weaver, P., Channell, J., Torii, M. and Hawthorne, T., 1990. Planktonic foraminiferal events and stable isotope records in the upper Miocene, Site 654. In: K.A. Kastens, J. Mascle et al. Proc. ODP, Sci. Results, 107: 415-427.

Hilgen, F.J. and Langereis, C.G., 1988. The age of the Miocene-Pliocene boundary in the Capo Rossello area (Sicily). Earth Planet. Sci. Lett., 91: 214-222.

Hodell, D.A. and Kennett, J.P., 1986. Late Miocene-Early Pliocene stratigraphy and paleoceanography of the South Atlantic and Southwest Pacific: a synthesis. Paleoceanography, 1: 285-311.

Kastens, K.A. and Mascle, J., 1990. The geological evolution of the Tyrrhenian Sea: an introduction to the scientific results of ODP Leg 107. In: K.A. Kastens, J. Mascle et al., Proc. ODP, Sci. Results, 107: 3-26.

Kennett, J.P. and Watkins, N.D., 1974. Late Miocene-Early Pliocene paleomagnetic stratigraphy, paleoclimatology, and biostratigraphy in New Zealand. Geol. Soc. Am. Bull., 85: 1385-1398.

Kirschvink, J.L., 1980. The least-squares line and plane and the analysis of paleomagnetic data. Geophys. J.R. Astron. Soc., 62: 699-718.

Langereis, C.G., 1984. Late Miocene magnetostratigraphy in the Mediterranean. Ph.D. Thesis, University of Utrecht. Geol. Ultraiectina, 34: $180 \mathrm{pp}$.

Langereis, C.G., Zachariasse, W.J. and Zijderveld, J.D.A., 1984. Late Miocene magnetobiostratigraphy of Crete. Mar. Micropaleontol., 8: 261-281.

Loutit, T.S. and Kennett, J.P., 1979. Application of carbon isotope stratigraphy to Late Miocene shallow marine sediments, New Zealand. Science, 204: 392-397.

Lowrie, W. and Heller, F., 1982. Magnetic properties of marine limestones, Rev. Geophys. Space Phys., 20(2): 171192.

Moreau, M.G., Feinberg, H. and Pozzi, J.P., 1985. Magnetobiostratigraphy of a Late Miocene section from the Moroccan Atlantic margin. Earth Planet. Sci. Lett., 76: 167175.

Pullaiah, G., Irving, E., Buchan, K.L. and Dunlop, D.J., 1975. Magnetization changes caused by burial and uplift. Earth Planet. Sci. Lett., 28: 133-143. 
Scott, G.H., 1980. Upper Miocene biostratigraphy: does Globorotalia conomiozea occur in the Messinian? Rev. Esp. Micropal., 12: 489-506.

Theodorides, S.A., 1984. Miocene calcareous nannoplankton zonation and revision of the genera Discoaster and Helicosphaera. Utrecht Micropal. Bull., 32: 272 pp.

Turner, G.M., Roberts, A.P., Laj, C., Kissel, C., Mazaud, A., Guitton, S. and Christoffel, D.A., 1989. New paleomagnetic results from Blind River: Revised magnetostratigraphy and tectonic rotation of the Marlborough region, South Island, New Zealand. N.Z. J. Geol. Geophys., 32: 191-196.

Van der Zwaan, G.J., 1979. The pre-evaporite Late Miocene environment of the Mediterranean; stable isotopes of planktonic foraminifera from section Falconara, Sicily. Proc. K. Ned. Akad., Series B, 82: 487-502.

Van der Zwaan, G.J., 1982. Paleoecology of Late Miocene Mediterranean foraminifera. Utrecht Micropal. Bull., 25: 202 pp.

Van der Zwaan, G.J. and Gudjonsson, L., 1986. Middle
Miocene-Pliocene stable isotope stratigraphy and paleoceanography of the Mediterranean. Mar. Micropal., 10: 71-90.

Zachariasse, W.J., 1979a. Planktonic foraminifera from Potamidha I: taxonomic and phyletic aspects of keeled Globorotaliids and some environmental estimates. Utrecht Micropal. Bull, 21: 129-166.

Zachariasse, W.J., 1979b. The origin of Globorotalia conomiozea in the Mediterranean and the value of its entry level in biostratigraphic correlations. Ann. Géol. Pays Hell., Tome Hors Série, III: 1281-1292.

Zachariasse, W.J. and Spaak, P., 1983. Middle Miocene to Pliocene paleoenvironmental reconstruction of the Mediterranean and adjacent Atlantic Ocean: planktonic foraminiferal record of southern Italy. Utrecht Micropal. Bull., 30: 91-110.

Zijderveld, J.D.A., Zachariasse, W.J., Verhallen, P.J.J.M. and Hilgen, F.J., 1986. The age of the Miocene-Pliocene boundary. Newsl. Stratigr., 16: 169-181. 